\title{
Crohn hastalığının duodenal tutulumu: olgu sunumları
}

\author{
Duodenal involvement of Crohn disease: case reports
}

Muhammet Yener AKPINAR, Fatih SAYGILI, Ilyas TENLIK, Ufuk Barış KUZU, Zeki Mesut Yalın KILIÇ, Yasemin ÖZDERIN ÖZIN, Erkin ÖZTAŞ, Ertuğrul KAYAÇETIN

Türkiye Yüksek Ihtisas Eğitim ve Araștırma Hastanesi, Gastroenteroloji Bölümü, Ankara

Crohn hastalı̆̆ı gastrointestinal sistemin kronik inflamatuvar bir hastalığıdır. Crohn hastalığında duodenal tutulum sıklığ \%0,5-5'lerdedir. Steroid, azatiyopürin ve anti-tümör nekrozis faktör grubu ilaçlar hastalarda etkin olarak kullanılabilir. Ilaç tedavisine yanıtsızlık halinde, fistül ve striktür varlığında ise tedavi cerrahidir.

Anahtar kelimeler: Crohn, duodenum
Crohn's disease is a chronic inflammatory condition of gastrointestinal system. Duodenal involvement varies between 0,5\%-5\% in crohn's disease. Steroids, azathioprine and anti-TNF drugs are effectively use in medical treatment of this condition. Surgery is a treatment option if there is stricture, fistula or failure of medical treatment.

Key words: Crohn, duodenum

pürin ve daha sonra adalimumab tedavisi eklenilen hastanın yapılan kontrol endoskopilerinde darlığın ve ülserlerin sebat ettiği görüldü. Darlık için yapılan ilk balon dilatasyonundan sonra beslenmesi kısmen düzelen hastanın bir hafta içinde şikayetleri tekrarladı. Darlık için daha sonra balon dilatasyon tekrarlansa da şikayetlerinde düzelme olmadı. Baryumlu grafide duodenum 3. kesimde duvar düzensiz olup 3-4. kesim düzeyinde lümen daralmış olarak izendi ve bu düzeyin proksimalinde duodenum $7 \mathrm{~cm}$ olarak ölçüldü (Resim 1). Medikal tedaviye ve balon dilatasyonlara yanıtsız kabul edilen hastaya cerrahi planlanıldı.

\section{OLGU SUNUMU-2}

32 yaşında erkek hasta kliniğimize karın ağrısı, bulantı ve kusma şikayetleri ile başvurdu. Fizik muayenesi, epigastrik alandaki hafif hassasiyeti dışında normaldi. Laboratuvarında hemoglobin: 11,9 gr/dl, alanin aminotransferaz: 13U/L $(<50)$, aspartat aminotransferaz: $17 \mathrm{U} / \mathrm{L}(<50)$, total protein: $4,5 \mathrm{gr} / \mathrm{dL}(6,6-8,3)$ albumin: $2,6 \mathrm{~g} / \mathrm{dL}(3,5-5,2)$, sedimentasyon: $29 \mathrm{~mm} / \mathrm{h}$ ve C-reaktif protein: $20,2 \mathrm{mg} / \mathrm{L}$ olarak izlendi. Endoskopisinde duodenum 3. kısımda mukoza hiperemik, granüler ve ödemli olup yer yer tabanlarında eksuda bulunan nodüler alanlara paralel uzanan ve derinlik arz eden ülserler izlendi, kenarlarından biyopsiler alındı (Resim 2). Patolojide incelenen kesitlerde villus kaybı, kriptlerde distorsiyon, dallanma, pilorik gland metaplazisi ve kriptit gösteren, normal yapısını yitirmiş duodenum mukozaları izlendi. Çölyak için 
bakılan otoantikorları negatif gelince duodenal Crohn hastalığı olarak düşünüldü. Abdominal tomografisinde duodenum 3. ve 4. kısımlarında treitze ligamentine kadar uzanım gösteren, en derin yerinde 15 mm'ye ulaşan diffüz duvar kalınlaşması izlendi. Tomografisinde ayrıca terminal ileumda da duvar kalınlaşması vardı. Enteroklizis yapılan hastada tomografiye benzer şekilde duodenum 3-4. kesimden jejunum proksimaline uzanan, opak madde geçişine izin veren yaklaşı $13 \mathrm{~cm}$ uzunluğunda segmenter darlık tespit edildi (Resim 3). Kolonoskopisi planlanıldı ancak kirlilikten dolayı sigmoid kolondan proksimale gidilemedi. Tedavi olarak prednisolon ve azatiyopürin başlanılan hastanın şikayetleri belirgin olarak düzeldi.

\section{TARTIŞMA}

Crohn hastalığında gastroduodenal tutulum \%5'e varan siklikta izlenir. Bununla beraber üst gastrointestinal sistem tutulumu sanıldığından daha fazladır. Çoğu Crohn hastasının aldığı tedaviler, üst gastrointestinal sistem tutulumlarına bağlı oluşabilecek şikayetleri ortadan kaldırabilir. Üst gastrointestinal sistem anormallikleri çift-kontrast grafilerde \%20 -40 , endoskopilerde \%20-30 ve histolojik incelemelerde \%30-50'lerdedir (2). Hastalığın duodenumda en sik tuttuğu yer bulbustur. Gastroduodenal tutulumun görülme siklığ açısından erkek ve kadınlar arasında fark yoktur.

Gastroduodenal tutulumu olan hastaların çoğu asemptomatiktir. Semptomatik hastalarda en sık izlenen şikayetler epi-

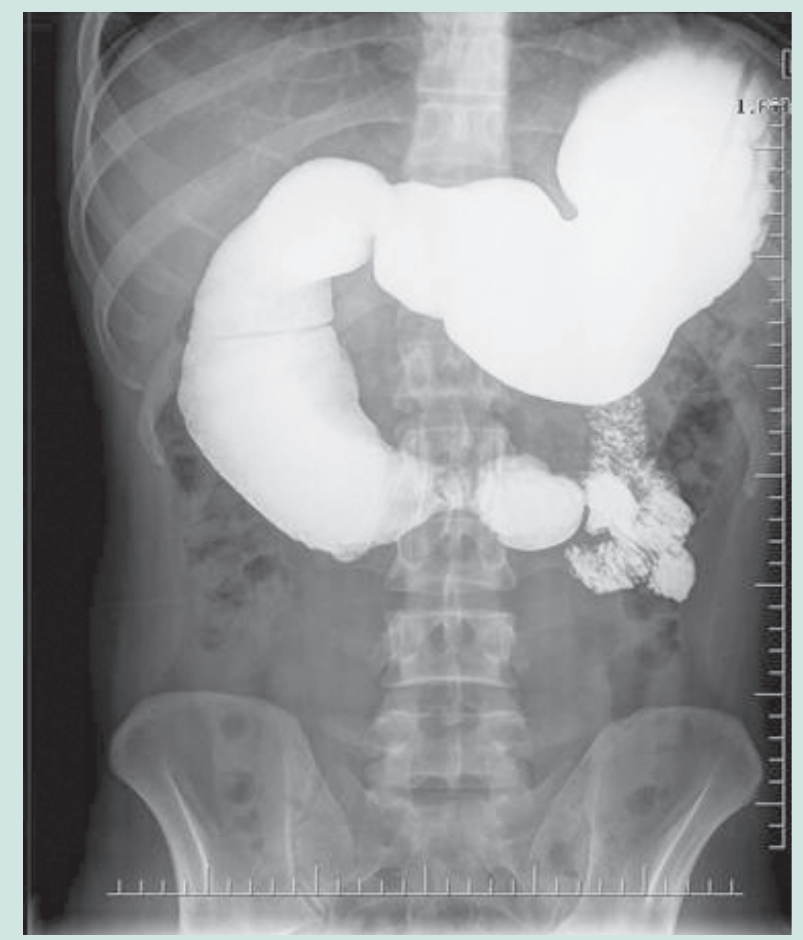

Resim 1. Baryumlu grafide duodenumda darlık ve proksimalinde 7 $\mathrm{cm}^{\prime}$ ye varan dilatasyon.

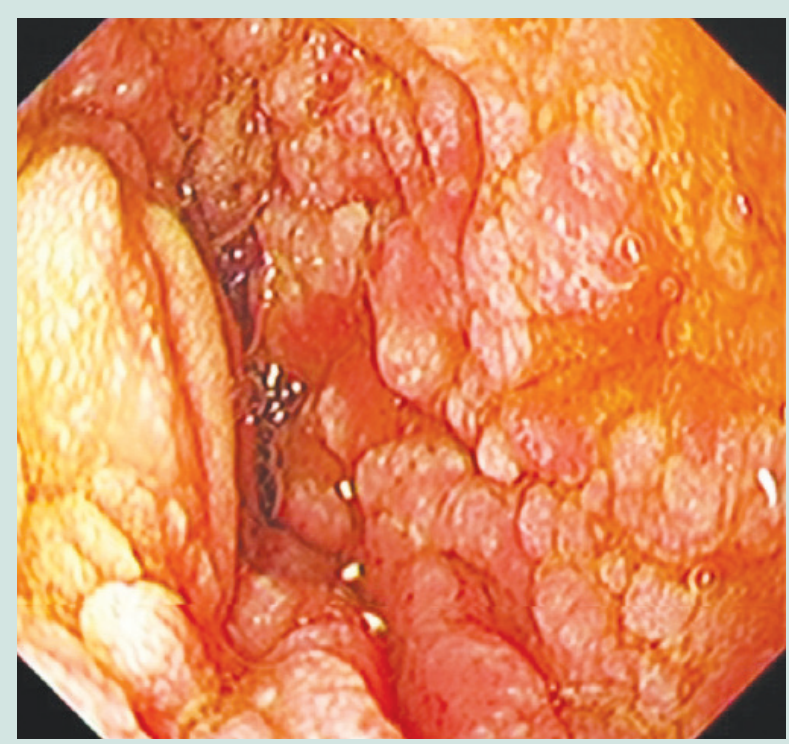

Resim 2. Duodenum mukozasının ödemli ve nodüler görünümü.

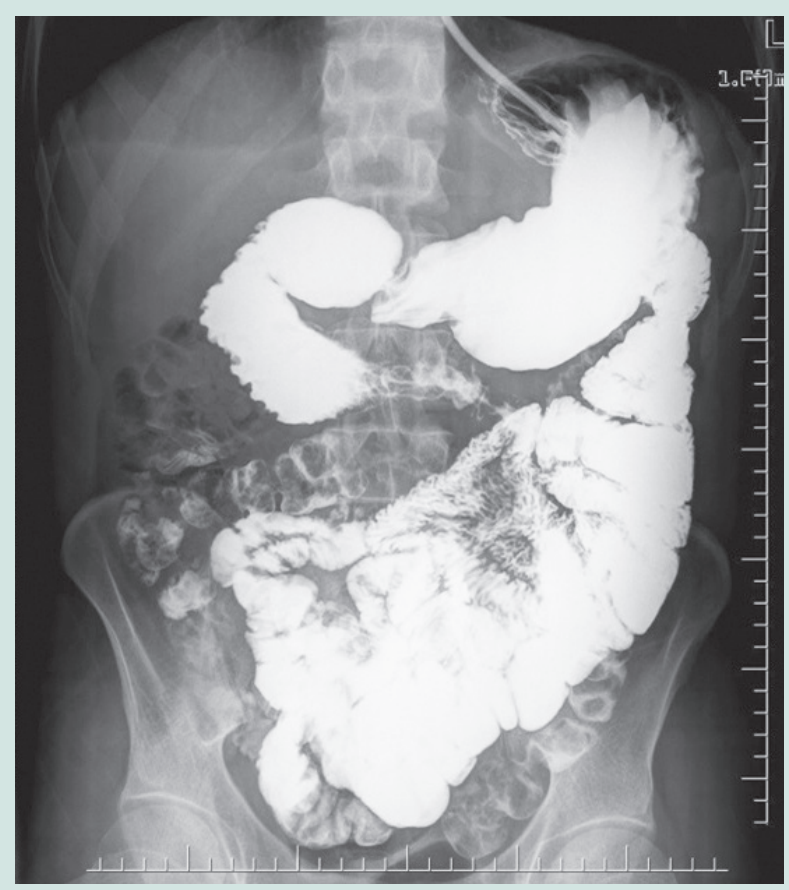

Resim 3. Enterokliziste duodenal darlık.

gastrik ağrı, iştahsızlık, kilo kaybı, şişkinlik bulantı ve kusmadır (3). Daha nadir olarak bu hastalarda kanamalar da olabilir. Bununla beraber aşikar kanama nadirdir. Baryumlu grafiler, endoskopi ve biyopsi tanı ve ayırıcı tanıda faydalıdır. Baryumlu grafilerde 'koç boynuzu' olarak bilinen görünüm nadir olmakla beraber tanısaldır (4). Aftöz ülserler endoskopide izlenen erken lezyonlardandır. Mukozal eritem, frajilite, nodülarite, lineer ülserler ve striktürler endoskopide görülebilecek diğer lezyonlardır. Bu tutulum şekilleri ile gastroduo- 
denal Crohn hastalığının eozinofilik gastroenterit, sarkoidoz, lenfoma, peptik ülser gibi hastalıklarla ayırıcı tanısı yapılmalıdır. Gastroduodenal Crohn hastalığının en sık komplikasyonu striktürlere bağlı gelişen gastrik çıkış yolu obstrüksiyonudur. Diğer bir komplikasyon da fistül formasyonu olup duodenumla kolon, biliyer sistem, ince barsak ve pankreas arasında oluşabilir (5).

Gastroduodenal tutulumlu Crohn hastalığının tedavisi medikal veya cerrahidir. Kanıta dayalı bir tedavi kılavuzu olmadığı için gastroduodenal tutulumlu Crohn hastalığında medikal tedavi klinik gözlem ve teorik bilgiye dayanır (6). Proton pompa inhibitörleri ile yapılan asit baskılayıcı tedavi bir k1sim hastada etkili olabilir. 5-aminosalisilik asit preparatlarının bu hastalarda tedavide yeri yoktur (6). Steroidler remis-

\section{KAYNAKLAR}

1. Farmer RG, Whelan G, Fazio VW. Long-term follow-up of patients with Crohn's disease. Relationship between the clinical pattern and prognosis. Gastroenterology 1985;88:1818-25.

2. Reynolds HL Jr, Stellato TA. Crohn's disease of the foregut. Surg Clin North Am 2001;81:117-135.

3. Nugent FW, Roy MA. Duodenal Crohn's disease: an analysis of 89 cases. Am J Gastroenterol 1989;84:249-54.

4. van Hogezand RA, Witte AM, Veenendaal RA, et al. Proximal Crohn's disease: review of the clinicopathologic features and therapy. Inflamm Bowel Dis 2001;7:328-37. yon indüksiyonunda kullanılan etkili ajanlardır. Steroidlerin kesilmesiyle hastalarda nüks sık olarak izlenir. Azatiyopürin idame tedavide kullanılabilen ve inflamasyonu baskılayarak şikayetleri azaltan bir ilaçtır. Anti-tümör nekrozif faktör ilaçlar da bu grup hastalarda kullanılmaktadır. Bazı çalışmalar infliximab tedavisinin etkili olabileceğini göstermiştir (7). Medikal tedaviye yanıtsız veya striktür gelişen hastalarda cerrahi tedaviler gündeme gelebilir. Bu hastalarda temel olarak uygulanabilen cerrahi yöntemler rezeksiyon, by-pass ve striktüroplastidir. Rezeksiyon yüksek morbidite ve mortaliteyle beraberdir. Bundan dolayı tercih edilen yöntemler by-pass ve striktüroplastidir. By-pass cerrahisi teknik olarak daha uygulanabilir bir yöntem olsa da marjinal ülserler, safra reflüsü gibi komplikasyonlara yol açabilir (8).

5. Rutgeerts P, Onette E, Vantrappen G, et al. Crohn's disease of the stomach and duodenum: a clinical study with emphasis on the value of endoscopy and endoscopic biopsies. Endoscopy 1980;12:288-94.

6. Tremaine WJ. Gastroduodenal Crohn's disease: Medical management. Inflamy Bowel Dis;9:127-8.

7. Firth M, Prather C. Unusual gastric Crohn's disease treated with infliximab-A case report. Am J Gastroenterol 2002;97:S190.

8. Worsey MJ, Hull T, Ryland L, Fazio V. Strictureplasty is an effective option in the operative management of duodenal Crohn's disease. Dise Colon Rectum 1999;42:596-600. 